\title{
Creatine metabolism in the seminiferous epithelium of rats. I. Creatine synthesis by isolated and cultured cells
}

\author{
N. P. Moore ${ }^{1 *}$, T. J. B. Gray ${ }^{2}$ and J. A. Timbrell ${ }^{1 \dagger}$ \\ ${ }^{1}$ Toxicology Department, The School of Pharmacy, University of London, 29-39 Brunswick Square, \\ London WCIN IAX, UK; and ${ }^{2}$ Pharmaceuticals Research Division, Sanofi Winthrop Research Centre, \\ Willowburn Avenue, Alnwick, Northumberland NE66 2JH, UK
}

\begin{abstract}
The testis synthesizes creatine from both arginine and glycine precursors, but when rat testicular tissue is separated into seminiferous tubules and interstitial cells, creatine synthesis occurs only in the tubular fraction. The purpose of the work presented here was to define the locus of creatine synthesis within the seminiferous tubules, by using cell separation and culture techniques to examine synthesis in the Sertoli cells and germ cells. The total creatine content, in the cellular compartment and incubation medium, of Sertoli-germ cell co-cultures and of Sertoli cell-enriched cultures, largely free of germ cells, increased by similar amounts over a $24 \mathrm{~h}$ incubation period. Sertoli cell-enriched cultures incorporated radioactivity from $\mathrm{L}$-[guanidino- $\left.{ }^{14} \mathrm{C}\right]$ arginine and $\left[1-{ }^{14} \mathrm{C}\right]$ glycine into both creatine and its biosynthetic precursor, guanidinoacetic acid. Isolated germ cells did not incorporate radioactivity from L-[guanidino- ${ }^{14} \mathrm{C}$ ]arginine into either creatine or guanidinoacetic acid when incubated at a similar density and protein concentration under similar conditions. It is concluded that the synthesis of creatine osberved in isolated rat seminiferous tubules occurs within the Sertoli cells and not the germ cells.
\end{abstract}

\section{Introduction}

Creatine is synthesized in two stages. The amidine group from arginine is transferred to glycine, in a reaction catalysed by the enzyme glycine amidinotransferase, to produce guanidinoacetic acid. Guanidinoacetic acid is then methylated by guanidinoacetate methyltransferase to creatine. Both of these stages are carried out in the liver and pancreas in humans, but in a number of laboratory animals, including rats, the transamidination reaction occurs predominantly in the kidneys and the methylation reaction in the pancreas. These pathways have also been described in other organs, including the testis (Walker, 1979).

Creatine synthesis in the testes of a number of species, including rats, was first described after tissue fragments were incubated in the presence of $\left[{ }^{14} \mathrm{C}\right]$ glycine. Guanidinoacetic acid synthesis was not detected, although it did occur in kidney tissue incubated under the same conditions (Alekseeva and Tkachenko, 1961; Alekseeva and Arkhangel'skaya, 1964). These authors proposed that a unique pathway for creatine synthesis might exist within the testis. The synthesis of creatine and guanidinoacetic acid was later reported in the testes of anaesthetized rats after the organs were directly injected with L-Iguanidino- ${ }^{14}$ Clarginine (Koszalka, 1968). Activity of glycine amidinotransferase and guanidinoacetate

\footnotetext{
*Current address: BP Chemicals Limited, Chertsey Road, Sunbury on Thames, Middlesex, TW16 7LN, UK.

${ }^{+}$Correspondence and reprint requests to current address: Department of Pharmacy, King's College London, Manresa Road, London SW3 6LX, UK Received 23 June 1997.
}

methyltransferase has been reported in the testes of a number of mammalian species, including rats (Salvatore and Schlenk, 1962; van Pilsum et al., 1963, 1972).

Previous results suggested that testicular creatine in rats is localized within the seminiferous epithelium (Moore et al., 1992), and that seminiferous tubules isolated from mature and immature rats synthesize creatine and guanidinoacetic acid when incubated in the presence of $\mathrm{L}$-[guanidino $-{ }^{14} \mathrm{C}$ ]arginine (Moore et al., 1989). The purpose of the work presented here was to determine the cellular locus of creatine synthesis within the seminiferous epithelium of rats.

\section{Materials and Methods}

\section{Materials}

Male, Sprague-Dawley rats were supplied by Harlan Olac (Bicester) at 21 days of age. L-[guanidino- ${ }^{14} \mathrm{C}$ arginine monohydrochloride $\left(54.4 \mu \mathrm{Ci} \mu \mathrm{mol}^{-1}\right)$ and $\left[1_{-14}{ }^{14} \mathrm{C}\right] g l y c i n e ~(56 \mu \mathrm{Ci}$ $\mathrm{mol}^{-1}$ ) were obtained from Amersham International plc (Aylesbury). [1- $\left.{ }^{14} \mathrm{C}\right] c r e a t i n e ~\left(13.5 \mu \mathrm{Ci} \mu \mathrm{mol}^{-1}\right)$ was from ICN Radiochemicals (Irvine, CA). 'Aquasol' was from New England Nuclear plc (Edinburgh), and 'betavials' were supplied by Hughes and Hughes (Wellington). Micropak MCH-10 ODS and Vydac reverse phase materials were from Varian Ltd (Warrington).

Cell culture stocks and reagents were supplied by Gibco Ltd (Paisley) and all other chemicals and reagents were from Sigma or BDH Ltd (Poole). 


\section{Cell isolation and culture}

Sertoli-germ cell co-cultures were prepared from the testes of 28-day-old rats by the method of Gray and Beamand (1984), and plated out onto $35 \mathrm{~mm}$ or $50 \mathrm{~mm}$ plastic culture dishes. Uniform plating density was ensured by maintaining the cell suspension by gentle pipetting, and by applying equal volumes of cell suspension to each culture dish. After incubation for $48 \mathrm{~h}$, germ cells were removed by hypotonic shock treatment (Galdieri et al., 1981) to produce Sertoli cell-enriched cultures, which were incubated for a further $24 \mathrm{~h}$ before use. Both Sertoli-germ cell co-cultures and Sertoli cell-enriched cultures were incubated in supplemented Eagle's minimal essential medium (EMEM) (Gray and Beamand, 1984).

A crude germ cell isolate, prepared from the testes of 35-day-old Sprague-Dawley rats essentially as described by Meistrich (1977), was incubated in Earle's balanced salt solution (EBSS) supplemented with $2 \mathrm{mmol}$ pyruvate $\mathrm{I}^{-1}$ and $6 \mathrm{mmol}$ L-lactate $~^{-1}$. Contaminating Sertoli cells, characterized by large pale nuclei under light microscopy, made up $7-9 \%$ of the cell population.

Determination of total creatine and creatine synthesis in cultures of testicular cells

Sertoli cell-enriched cultures were prepared from Sertoli-germ cell co-cultures, and both cultures were then incubated in parallel to determine the total amount of creatine (that is, in the cells and medium) at $\mathrm{Oh}$ and $24 \mathrm{~h}$ after replacement of the medium. The cells were scraped into the culture medium using a rubber policeman and sonicated. Creatine was determined by a modification of a standard fluorimetric method (Moore et al., 1998).

\section{Radiometabolism studies}

Sertoli cell-enriched cultures or freshly isolated germ cells were incubated for $24 \mathrm{~h}$ in the presence of the radiolabelled precursors at a final activity of $0.17 \mu \mathrm{Ci} \mathrm{ml}^{-1}, 0.28 \mu \mathrm{Ci} \mu \mathrm{mol}^{-1}$ (L-[guanidino- ${ }^{14} \mathrm{C}$ ]arginine) or $0.15 \mu \mathrm{Ci} \mathrm{ml}{ }^{-1}, 1.5 \mu \mathrm{Ci} \mu \mathrm{mol}^{-1}$ $\left(\left[1-{ }^{14} \mathrm{C}\right]\right.$ glycine $)$. At the end of the incubation period, the cells were scraped into the medium, which was then sonicated. A carrier solution of guanidinoacetic acid and creatine hydrate ( $1 \mathrm{mg} \mathrm{ml}{ }^{-1}, 10 \% \mathrm{v} / \mathrm{v}$ ) was added and the samples were boiled for $5 \mathrm{~min}$ and centrifuged at $2700 \mathrm{~g}$ for $5 \mathrm{~min}$. An aliquot $(40-50 \mu \mathrm{l})$ of each sample was applied directly to the column.

Radiometabolites were separated by HPLC, using an adaptation of the method described by Moore et al. (1989). Briefly, the main column (i.d. $300 \mathrm{~mm} \times 4 \mathrm{~mm}$ ) was packed with a $\mathrm{C}_{18}, 10 \mu \mathrm{m}$ pellicular reverse phase material (Micropak MCH-10 ODS) and the guard column (i.d. $25 \mathrm{~mm} \times 4 \mathrm{~mm}$ ) was packed with Vydac reverse phase material. The mobile phase consisted of an aqueous solution of $10 \mathrm{mmol} \mathrm{Na} \mathrm{SO}_{4}$ $\mathrm{l}^{-1}, 5 \mathrm{mmol} \mathrm{H}_{2} \mathrm{SO}_{4} \mathrm{l}^{-1}$, and $5 \mathrm{mmol}$ sodium 1 -hexane sulfonate $\mathrm{I}^{-1}$; the final $\mathrm{pH}$ was adjusted to 2.2 with $\mathrm{H}_{2} \mathrm{SO}_{4}$. Separation was effected by a flow programme, with an initial flow rate of $1 \mathrm{ml} \mathrm{min}^{-1}$ maintained for $8 \mathrm{~min}$, increasing to $2 \mathrm{ml} \mathrm{min}^{-1}$ over a $1 \mathrm{~min}$ period. After $4 \mathrm{~min}$, it was further increased to $3 \mathrm{ml} \mathrm{min}{ }^{-1}$ over another 1 min period. This flow rate was maintained for a further $16 \mathrm{~min}$, when it was returned

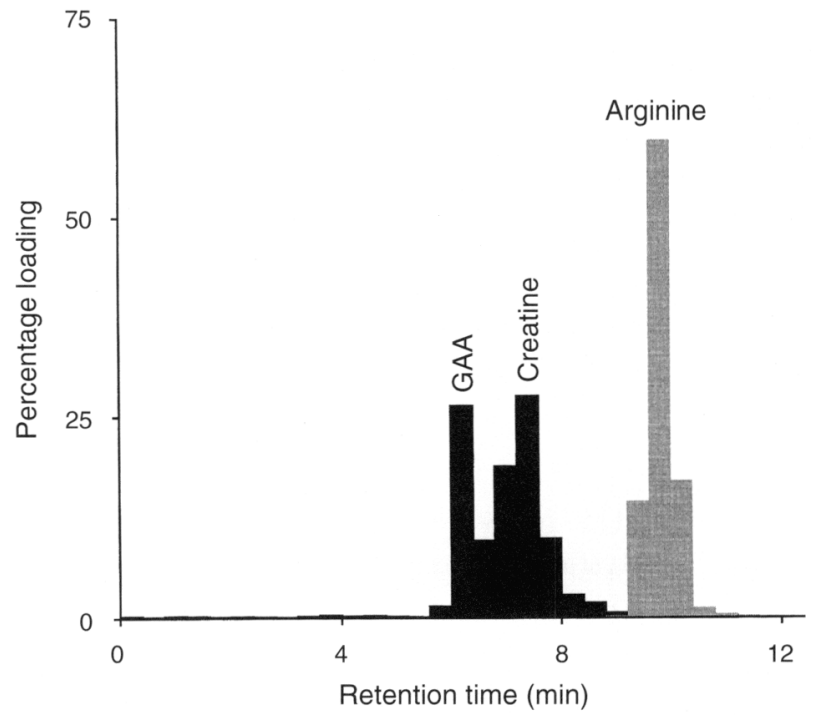

Fig. 1. Validation of the HPLC radiochromatographic method. Standard solutions of $\left[1-{ }^{14} \mathrm{C}\right]$ guanidinoacetic acid (GAA) and

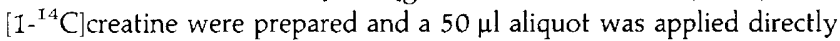
to the column ( $)$. A separate radiochromatogram for a solution of L-[guanidino $-{ }^{14} \mathrm{C}$ ]arginine is shown for comparison $(\boldsymbol{\square})$. The vertical axis (percentage loading) refers to the radioactivity of each fraction expressed as a percentage of the total radioactivity applied to the HPLC column.

to $1 \mathrm{ml} \mathrm{min}{ }^{-1}$ over $3 \mathrm{~min}$. The effluent was collected into 'betavials' in $0.4 \mathrm{~min}$ fractions over the first $13 \mathrm{~min}$, and radioactivity determined by liquid scintillation counting.

This method has been validated with authentic samples of $\left[{ }^{14} \mathrm{C}\right]$ creatine, $\left[{ }^{14} \mathrm{C}\right]$ guanidinoacetic acid and $\mathrm{L}-\left[{ }^{14} \mathrm{C}\right]$ arginine. A standard solution of $\left[1-{ }^{14} \mathrm{C}\right]$ guanidinoacetic acid and $\left[1-{ }^{14} \mathrm{C}\right]$ creatine was prepared by mixing aqueous solutions of $\left[1-{ }^{14} \mathrm{C}\right.$ guanidinoacetic acid $\left(1.72 \mu \mathrm{Ci} \mathrm{mmol}{ }^{-1}, 25 \mu \mathrm{g} 50 \mu \mathrm{l}^{-1}\right)$ and creatine hydrate $\left(25 \mu \mathrm{g} 50 \mu^{-1}\right)$, and then adding $\left[1-{ }^{14} \mathrm{C}\right]$ creatine $\left(13.5 \mu \mathrm{Ci} \mu \mathrm{mol}^{-1}\right)$ to an approximately equal activity. A $50 \mu \mathrm{l}$ aliquot was applied directly to the column (Fig. I)

\section{Other assays}

Intracellular metabolites were measured in single cultures. Cells were washed with isotonic saline, scraped into a measured volume $(2 \mathrm{ml})$ of fresh saline, and then sonicated. Creatine, $\mathrm{N}$ phosphorylcreatine, creatine $N$-phosphoryltransferase activity, and protein were determined by described methods (Lowry et al., 1951; Horder et al., 1979; Yasuhara et al., 1982; Loike et al., 1984), except that the incubation temperature used for the creatine $N$-phosphoryltransferase assay was $32^{\circ} \mathrm{C}$. One unit of creatine $N$-phosphoryltransferase was defined as the activity required to dephosphorylate $N$-phosphorylcreatine at a rate of $1 \mu \mathrm{mol} \mathrm{min}^{-1}$ at a temperature of $32^{\circ} \mathrm{C}$.

Cell viability was determined by the ability to exclude a vital dye (Trypan blue, $0.4 \%$ in isotonic saline solution).

\section{Synthesis of $\left[1-{ }^{14} \mathrm{C}\right]$ guanidinoacetic acid HPLC standard}

$\left[1-{ }^{14} \mathrm{C}\right]$ Guanidinoacetic acid was synthesized from $\left[1-{ }^{14} \mathrm{C}\right]$ glycine as described by Dubnoff (1957). Glycine 
(383 $\mathrm{mg}, 5.10 \mathrm{mmol})$ was dissolved in water $(4 \mathrm{ml})$ with $\left[1-{ }^{14} \mathrm{C}\right]$ glycine $(9 \mu \mathrm{Ci})$. Cyanamide $(500 \mathrm{mg})$ and concentrated ammonia solution ( 3 drops) were added. The solution was left at room temperature for $72 \mathrm{~h}$, and then at $4^{\circ} \mathrm{C}$ overnight. The precipitated solid was washed five times by repeated re-crystallization from the minimum of hot water, and dried overnight at $70^{\circ} \mathrm{C}$. The chemical purity was $>99 \%$, as indicated by elemental analysis and HPLC. The radiochemical purity, also determined by HPLC, was found to be $>95 \%$. A specific activity of $1.72 \mu \mathrm{Ci} \mathrm{mmol}^{-1}$ was determined.

\section{Results}

The distribution of creatine, N-phosphorylcreatine and creatine $\mathrm{N}$-phosphoryltransferase activity within the seminiferous epithelium

Germ cells appeared to contain a higher concentration of creatine than Sertoli cells $(260$ and $90 \mathrm{nmol} \mathrm{mg}$ protein $^{-1}$, respectively) but similar amounts of creatine $\mathrm{N}$-phosphosyltransferase activity $\left(5.3\right.$ and $8.8 \mathrm{mU} \mathrm{mg}^{-1}$ protein, respectively) and $N$-phosphorylcreatine ( 9 and $17 \mathrm{nmol}$ $\mathrm{mg}^{-1}$ protein, respectively).

\section{Synthesis of creatine by Sertoli cell-enriched cultures and Sertoli-germ cell co-cultures}

The total creatine content (that is, cells and medium combined) of Sertoli cell-enriched cultures and Sertoli-germ cell co-cultures on $50 \mathrm{~mm}$ culture dishes are shown (Fig. 2). The results for $0 \mathrm{~h}$ reflect cellular creatine content, as EMEM does not contain creatine, and indicate that both Sertoli cells and germ cells contain creatine. The creatine content of Sertoli cell-enriched co-cultures represents that found in the Sertoli cells, while the difference between that of Sertoli cell-enriched cultures and Sertoli-germ cell co-cultures represents the content of the germ cells.

The total creatine content of both Sertoli cell-enriched cultures and Sertoli-germ cell co-cultures increased by approximately $44 \mathrm{nmol}$ over $24 \mathrm{~h}$, indicating that these cultures do synthesize creatine, but that the germ cells do not contribute significantly to this process.

Incorporation of radioactivity from precursors into guanidinoacetic acid and creatine by Sertoli cell-enriched cultures and isolated germ cells

Radiochromatographic profiles from the culture media in which Sertoli cell-enriched cultures and a crude germ cell isolate were incubated in the presence of radiolabelled precursors on $35 \mathrm{~mm}$ culture dishes for $24 \mathrm{~h}$ are shown (Fig. 3). Sertoli cell-enriched cultures were incubated in the presence of either L-[guanidino- $\left.{ }^{14} \mathrm{C}\right]$ arginine (Fig. 3a) or $\left[1-{ }^{14} \mathrm{C}\right.$ glycine (Fig. $3 b)$. Germ cells were incubated in the presence of L-lguanidino${ }^{14}$ Clarginine (Fig. 3c).

Sertoli cell-enriched cultures incorporated activity from L-[guanidino- ${ }^{14} \mathrm{C}$ ]arginine into both guanidinoacetic acid and creatine to the extent of $1.2 \%$ and $1.7 \%$, respectively (equivalent to 17.3 and $24.8 \mathrm{nmol}$ per dish per $24 \mathrm{~h}$ ). These cell

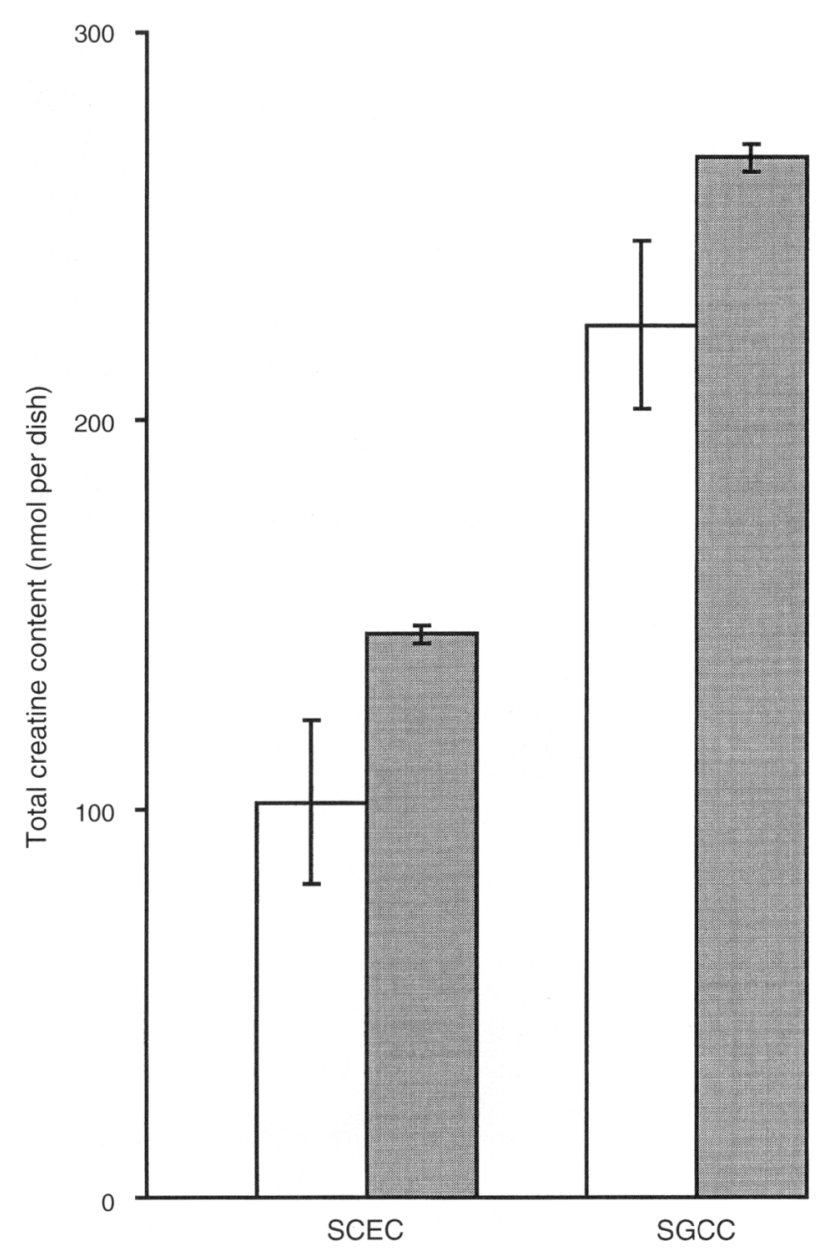

Fig. 2. The synthesis of creatine by Sertoli cell-enriched cultures (SCEC) and Sertoli-germ cell co-cultures (SGCC) from rat testes. The total creatine content (cells plus medium) of cultures was determined immediately $(0 \mathrm{~h}, \square)$ or $24 \mathrm{~h}$ ( $)$ after replacement of the incubation medium. The increase in creatine content over this time is a measure of its synthesis. Data represent means \pm SD of three dishes from one preparation that is representative of two experiments.

cultures also incorporated activity from $\left[1-{ }^{14} \mathrm{Clglycine}\right.$. Germ cells cultured at a similar protein density to the Sertoli cells $(0.254$ and $0.303 \mathrm{mg}$ protein per dish, respectively) did not synthesize these metabolites, although cells retained $>98 \%$ viability. The small creatine peak seen in the chromatogram from germ cells (labelled II) represents $<10 \%$ of the radioactivity seen in Sertoli cell-enriched cultures, and is probably a result of contamination by Sertoli cells.

\section{Discussion}

The data presented here have further elucidated the site of creatine synthesis within the rat testis. Previous work indicated that isolated rat seminiferous tubules synthesize creatine and guanidinoacetic acid from arginine (Moore et al., 1989), whereas interstitial tissue and boiled tubules do not have this capacity (Moore, 1993). We conclude from the data obtained from the present study that although creatine, its metabolite 

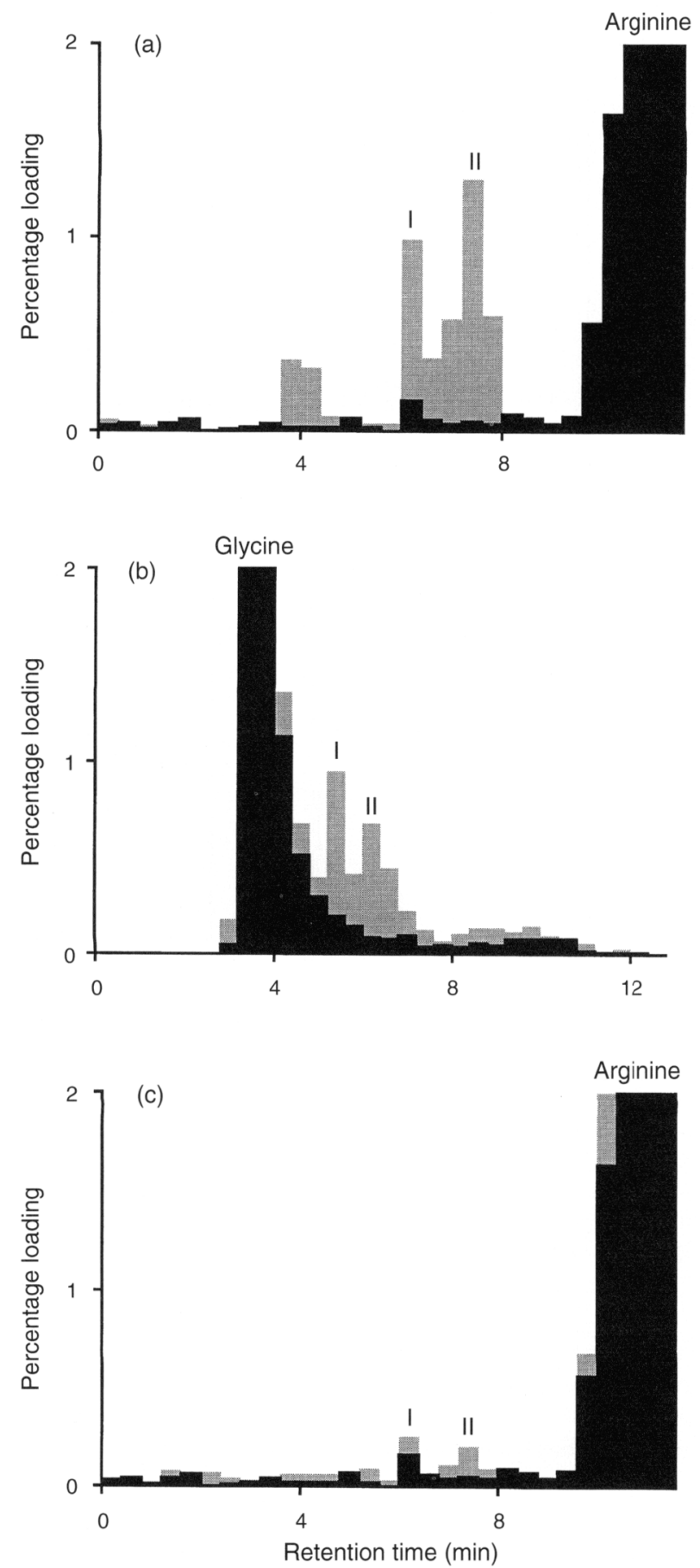

Fig. 3. Incorporation of radioactivity from L-\{guanidino- ${ }^{14} \mathrm{C}$ larginine and $\left[1-{ }^{14} \mathrm{C}\right.$ lglycine into creatine by cultured Sertoli cells and isolated germ cells from rat testes. Sertoli cell-enriched cultures $(a, b)$ and germ cells (c) were incubated for $24 \mathrm{~h}$ in Eagle's minimum essential medium containing either $(\mathrm{a}, \mathrm{c}) \mathrm{L}$-[guanidino $-{ }^{14} \mathrm{C}$ ]arginine, or $(\mathrm{b})\left[1-{ }^{14} \mathrm{C}\right]$ glycine. Both precursors were incorporated by Sertoli cell-enriched cultures into peaks that co-eluted with guanidinoacetic acid (peak I) and creatine (peak II), but germ cells expressed no significant activity. (중) Radiochromatograms from the incubation medium above the cells. (ם) Radiochromatograms of medium containing the radiolabelled precursor incubated without cells. The vertical axis (percentage loading) refers to the radioactivity of each fraction expressed as a percentage of the total radioactivity applied to the HPLC column.
$N$-phosphorylcreatine, and creatine $N$-phosphoryltransferase are distributed throughout the seminiferous epithelium, it is only the Sertoli cells that have the capacity to synthesize creatine from arginine. However, the possibility that germ cells may be able to synthesize creatine from guanidinoacetic acid, as has been shown for skeletal muscle, heart and brain tissue (Daly, 1985), cannot be discounted.

The extent of creatine phosphorylation measured in the cells of the seminiferous epithelium is relatively low $3.5 \%$ and $18.9 \%$ in germ cells and Sertoli cells, respectively, compared with $40-70 \%$ in muscle), but this is in general agreement with previously published data for the testis as a whole $(0-7 \%)$ (Navon et al., 1985; Lee et al., 1988). Phosphorylation in the germ cells represents only $20 \%$ of that in the Sertoli cells, yet creatine $N$-phosphoryltransferase activity is $60 \%$. The biological significance of this observation is unclear, but it may represent compartmentalization within the germ cells. The role of $N$-phosphorylcreatine in these cells is also unclear at the present time, but since creatine $N$-phosphoryltransferase activity in Sertoli cells is mainly, if not solely, localized at the basal lamina (Moore, 1993), it may play a role in energy supply to the cytoskeleton during transfer of leptotene spermatocytes across the blood-testis barrier.

If the total amount of creatine in the culture is measured immediately and $24 \mathrm{~h}$ after the replacement of the culture medium, the difference can be taken as a measure of creatine synthesis during this period. In the results presented here, Sertoli cell-enriched cultures and Sertoli-germ cell co-cultures synthesized creatine to a similar extent, indicating that Sertoli cells synthesize the majority of creatine, with germ cells making little, if any, contribution.

This conclusion was confirmed by the experiments in which Sertoli cell-enriched cultures and isolated germ cells were incubated with radiolabelled precursors for creatine synthesis. Whereas Sertoli cell-enriched cultures clearly synthesized creatine and guanidinoacetic acid from radiolabelled arginine and glycine, germ cells cultured at a similar density and protein concentration did not. The small creatine peak seen in the chromatogram from germ cells represents $<10 \%$ of the radioactivity seen in Sertoli cell-enriched cultures, and is probably a result of contamination by Sertoli cells.

The fact that Sertoli cells incorporate radioactivity from both arginine and glycine into creatine and guanidinoacetic acid demonstrates that these cells are capable of carrying out both stages of the 'classical' pathway for creatine synthesis. Therefore, it is unlikely that a unique pathway for creatine synthesis exists within the testis.

Although germ cells did not synthesize creatine from arginine, like Sertoli cells, they have the capacity for the phosphorylation of creatine, and they represent a substantial creatine pool. The question arises as to the source of this creatine. There are three obvious possibilities: creatine passing from the plasma through the Sertoli cell cytoplasm into the intratubular milieu; creatine synthesized by the Sertoli cells and released into the intratubular milieu; or guanidinoacetic acid synthesized by the Sertoli cells released into the intratubular milieu and sequestered and methylated by the germ cells themselves. These pathways would, of course, require a mechanism for creatine (or guanidinoacetic acid) uptake by the germ cells. Preliminary studies with isolated germ cells suggest 
that they have an active transport mechanism for creatine sequestration (Moore, 1993).

We have speculated that creatine (or guanidinoacetic acid) secreted by Sertoli cells is sequestered from the interstitial milieu by the germ cells, which then carry out further metabolism (phosphorylation of creatine and, possibly, methylation of guanidinoacetic acid). Much of the current work is based upon dissection of the epithelium, and examination of cells in isolation. The uncertainty that arises from using such techniques is that, under the culture conditions applied in this laboratory, the integrity of normal Sertoli-germ cell interactions is not maintained.

In the intact epithelium, the Sertoli cells surround the maturing germ cells, offering complex mechanical and biochemical support (Dym and Fawcett, 1970). Although some cellular interactions are re-established during co-culture of Sertoli cells and germ cells (Ziparo et al., 1980; Le Magueresse and Jégou, 1988), by the very nature of the physical and biochemical relationships, such isolation techniques result in cells that may not accurately reflect the activity of the cell populations in situ. Therefore, the interaction between these cells in regulating the pathway for creatine metabolism requires further clarification.

However, isolated seminiferous tubules do maintain the structure of the epithelium and are capable of synthesizing creatine (Moore et al., 1989). This observation supports the theory that cells of the epithelium carry out creatine synthesis, but the cellular location of the various stages in the metabolic pathway cannot be deduced from this heterogeneous structure, nor can any conclusions be drawn as to how the intercellular aspects of this pathway are regulated.

Thus, there is a significant dilemma in further defining the control and compartmentalization of the creatine pathway within the seminiferous epithelium. Cell culture techniques allow the pathway to be dissected and various stages to be studied in isolation, but have the drawback that interaction between the stages, and also the impact of cellular compartmentation, are lost. Moreover, Sertoli cells and germ cells maintained in isolation do not retain their normal functions. Alternatively, the integrity of the pathway can be sustained by the use of isolated tubules, but with a concomitant loss of precision in distinguishing its compartmentalization. The use of physiological or toxicological cell-specific modulators may allow tubules to be studied to greater effect. For example, isolation of tubules from cryptorchid testes would allow Sertoli cell activity to be determined in the absence of germ cells but with minimal disturbance to their relationship with other neighbouring Sertoli cells, although again such cells cannot be expected to retain their normal functions.

At present, the analysis of biochemical pathways associated with labile metabolites in a tissue as complex as the seminiferous epithelium is fraught with contradictions. Retention of the heterogeneous structure of the epithelium precludes the identification of specific physiological compartments, whereas isolation of cells represents a deviation from functional, as well as structural, normality. The interpretation of such data requires caution in considering the complexity of the epithelium and the cellular interactions therein.

A question that remains to be answered is if skeletal muscle, heart and brain tissue supplement their creatine pools solely from the blood, why does the testis have synthetic capacity rather than rely entirely upon uptake from the bloodstream? Free et al. (1976) suggested that some of the testicular blood flow may pass through non-metabolic routes, thereby bypassing the testicular parenchyma. Furthermore, the skeletal muscle alone represents a substantial and well supplied 'creatine sink'. Consequently, the full potential of the blood for supplementing the testicular creatine pool may not be realised. Alternatively, as the germ cells constitute the major metabolic mass of the testis, and a substantial creatine pool, the rate of creatine transport across the blood-testis barrier may be rate-limiting, thus requiring a localized synthesis.

Hyperthyroidism increases creatine concentrations in the blood and urine, resulting from a reduction in uptake by, and an increase in efflux from, skeletal and cardiac muscle (Kurahashi and Kuroshima, 1976, 1977). However, the reduction in the creatine content of skeletal and cardiac muscle after induced hyperthyroidism in rats is contrasted by an increase in the testicular content (Bodansky, 1935). This increase may be as a direct result of tri-iodothyronine action upon the testis, or by an increase in sequestration from the bloodstream facilitated by the increased creatine concentration in the plasma.

Until the nature of creatine sequestration by the testis is known, it is difficult to determine whether synthesis acts as a supplement to, or replacement for, uptake from the plasma. Whole testis perfusion with radiolabelled creatine may be useful in addressing this issue. However, the fact that the testis invests in the capacity to synthesize a metabolite which other organs obtain from external sources, suggests that uptake from the plasma does not fulfil the requirements of the testis for that metabolite.

This work was funded by grants from the Biotechnology and Biological Sciences Research Council and the British Industrial Biological Research Association.

\section{References}

Alekseeva AM and Arkhangel'skaya GG (1964) Two pathways of biosynthesis of creatine Biokhimiia 29 179-184

Alekseeva AM and Tkachenko AV (1961) Creatine synthesis in the testis Voprosy Meditsinskoi Khimii 7 324-325

Bodansky M (1935) The effect of the thyroid and thyroxine on the concentration of creatine in the heart, muscle, liver, and testes of the albino rat Journal of Biological Chemistry 109 615-622

Daly MM (1985) Guanidinoacetate methyltransferase activity in tissues and cultured cells Archives of Biochemistry and Biophysics 236 576-584

Dubnoff JW (1957) Glycocyamine and creatine. In Methods in Enzymology 3 pp 635-639 Eds SP Colowick and NO Kaplan. Academic Press, New York

Dym $M$ and Fawcett DW (1970) The blood-testis barrier in the rat and the physiological compartmentation of the seminiferous epithelium Biology of Reproduction 3 308-326

Free MJ, Schluntz GA and Jaffe RA (1976) Respiratory gas tensions in tissues and fluids of the male reproductive tract Biology of Reproduction 14 481-488

Galdieri M, Ziparo E, Palombi F, Russo MA and Stefanini M (1981) Pure Sertoli cell cultures: a new model for the study of somatic-germ cell interactions Journal of Andrology 5 249-254

Gray TJB and Beamand JA (1984) Effect of some phthalate esters and other testicular toxins on primary cultures of testicular cells Food and Chemical Toxicology 22 123-131

Hørder M, Magid E, Pitkänen E, Härkönen M, Strömme JH, Theodorsen L, Gerhardt W and Waldenström J (1979) Recommended method for the determination of creatine kinase in blood modified by the inclusion of EDTA Scandinavian Journal of Clinical and Laboratory Investization 39 1-5

Koszalka TR (1968) Creatine synthesis in the testis Proceedings of the Society for Experimental Biology and Medicine 128 1130-1137 
Kurahashi M and Kuroshima A (1976) Mechanism of thyroid-induced creatinuria in the rat, with special reference to creatine synthesis in the liver and creatine loss from skeletal muscle Japanese Journal of Physiology 26 279-288

Kurahashi M and Kuroshima A (1977) Mechanism of triiodothyronine-induced creatinuria in the rat American Journal of Physiology 233 E91-E96

Le Magueresse B and Jégou B (1988) In vitro effects of germ cells on the secretory activity of Sertoli cells recovered from rats of different ages Endocrinology 22 1672-1680

Lee HJ, Fillers WS and lyengar MR (1988) Phosphocreatine, an intracellular high-energy compound, is found in the extracellular fluid of the seminal vesicles in mice and rats Proceedings of the National Academy of Sciences USA $857265-7269$

Loike JD, Kozler VF and Silverstein SC (1984) Creatine kinase expression and creatine phosphate accumulation are developmentally regulated during differentiation of mouse and human monocytes Journal of Experimental Medicine 159 746-757

Lowry OH, Rosebrough NH, Farr AL and Randall RJ (1951) Protein measurement with the folin phenol reagent Journal of Biological Chemistry $193265-275$

Meistrich ML (1977) Separation of spermatogenic cells and nuclei from rodent testes. In Methods in Cell Biology 15 pp 15-54 Ed. DM Prescott. Academic Press, New York

Moore NP (1993) Creatine Distribution and Metabolism within the Rat Testis: In Vivo and In Vitro Effects of Testicular Toxicants PhD Thesis, University of London

Moore NP, Gray TJB and Timbrell JA (1989) Isolated rat seminiferous tubules synthesise guanidoacetic acid and creatine from arginine Biochemical Society Transactions 17 520-521
Moore NP, Creasy DM, Gray TJB and Timbrell JA (1992) Urinary creatine profiles after administration of cell-specific testicular toxicants to the rat Archives of Toxicology 66 435-442

Moore NP, Gray TJB and Timbrell JA (1998) Creatine metabolism in the seminiferous epithelium of rats. II. Effect of modulators of cellular biochemical function on creatine secretion by cultured Sertoli cells Journal of Reproduction and Fertility 112 341-346

Navon G, Gogol E and Weissenberg R (1985) Phosphorus-31 and proton NMR analysis of reproductive organs of male rats Archives of Andrology 15 153-157

Salvatore F and Schlenk F (1962) A new assay of guanidinoacetate methyltransferase Biochimica et Biophysica Acta 59 700-702

van Pilsum JF, Olsen B, Taylor D, Rozycki T and Pierce JC (1963) Transamidinase activities, in vitro, of tissues from various mammals and from rats fed protein-free, creatine-supplemented, and normal diets Archives of Biochemistry and Biophysics 100 520-524

van Pilsum JF, Stephens GC and Taylor D (1972) Distribution of creatine, guanidinoacetic acid and the enzymes for their biosynthesis in the animal kingdom Biochemical Journal 126 325-345

Walker JB (1979) Creatine: biosynthesis, regulation and function Advances in Enzymology and Related Areas of Molecular Biology 50 177-242

Yasuhara M, Fujita S, Arisue K, Kohda K and Hayashi C (1982) A new enzymatic method to determine creatine Clinica Chimica Acta 122 181-188

Ziparo E, Geremia R, Russo MA and Stefanini M (1980) Surface interaction in vitro between Sertoli cells and germ cells at different stages of spermatogenesis American Journal of Anatomy 159 385-388 